\title{
Technè
}

La science au service de l'histoire de l'art et de la préservation des biens culturels

43 | 2016

Une Europe de la recherche en sciences du patrimoine

\section{Archlab: archives central to a new scientific information-sharing platform}

Joëlle Crétin and Clémence Raynaud

Translator. Elsa Bourguignon

\section{OpenEdition}

\section{Journals}

Electronic version

URL: http://journals.openedition.org/techne/622

DOI: $10.4000 /$ techne.622

ISSN: 2534-5168

Publisher

C2RMF

\section{Printed version}

Date of publication: 1 August 2016

Number of pages: 41-45

ISBN: 978-2-7118-6338-9

ISSN: 1254-7867

\section{Electronic reference}

Joëlle Crétin and Clémence Raynaud, « Archlab: archives central to a new scientific information-

sharing platform », Technè [Online], 43 | 2016, Online since 19 December 2019, connection on 28 July 2020. URL : http://journals.openedition.org/techne/622 ; DOI : https://doi.org/10.4000/techne.622

\section{(c) (†) $\ominus$}

La revue Technè. La science au service de l'histoire de l'art et de la préservation des biens culturels est mise à disposition selon les termes de la Licence Creative Commons Attribution - Pas d'Utilisation Commerciale - Pas de Modification 4.0 International. 
Joëlle Crétin

Clémence Raynaud

\section{ARCHLAB : les archives au centre d'une nouvelle plateforme d'échanges scientifiques}

Archlab: archives central to a new scientific information-sharing platform

Résumé. L'accès transnational proposé par le consortium CHARISMA (2009-2014) comprenait une nouvelle composante associant les archives de six laboratoires européens. Pour la première fois dans un projet consacré à l'étude scientifique du patrimoine, les chercheurs pouvaient bénéficier d'accès subventionnés dans ces laboratoires ainsi que d'un accompagnement dans leurs recherches par des ingénieurs et des documentalistes. L'article dresse le bilan de ces quatre années, qui révèle les multiples apports de ce programme inédit. Il s'attache à en évaluer les succès, à l'aune des résultats scientifiques (publications, partenariats) et des échanges ainsi favorisés entre de nombreuses institutions et chercheurs européens.

Mots-clés. Projet CHARISMA, accès transnational, patrimoine, laboratoire, archives scientifiques, British Museum, National Gallery of London, C2RMF, Prado, OPD, OCW-RCE.
Abstract. The transnational access programme offered by the CHARISMA consortium (2009-2014) included a new component: information stored in the archives of six European laboratories. In a programme focusing on the scientific study of cultural heritage, researchers could, for the first time, take advantage of subsidized access to these laboratories and the assistance of engineers and archivists in their research. This paper takes stock of these four years, which show the manifold contributions made by this unprecedented programme. It strives to assess the achievements, measured against scientific results (publications, partnerships) and the knowledge-sharing thus fostered between numerous European institutions and researchers.

Keywords. CHARISMA (Cultural Heritage Advanced Research Infrastructures) programme, transnational access, heritage, laboratory, scientific archives, British Museum, National Gallery, London; C2RMF, Prado, OPD, OCW-RCE.
Au sein de l'accès transnational (transnational access), le projet CHARISMA incluait un programme inédit impliquant les archives de six laboratoires : ARCHLAB. Piloté par la filière Archives et documentation du C2RMF ${ }^{1}$, ce programme consistait à subventionner des accès à la documentation et aux archives de laboratoires voués au patrimoine, situés dans cinq pays d'Europe : le British Museum et la National Gallery (Londres), le C2RMF (Paris), le musée du Prado (Madrid), l'OCW-RCE Cultural Heritage Agency of the Netherlands (Amsterdam) et l'Opificio delle Pietre Dure (Florence). Ces institutions conservent en effet des fonds documentaires exceptionnels, constitués depuis leur création remontant, pour les plus anciennes d'entre elles, aux années $1930^{2}$. Au même titre que les instruments et les installations scientifiques (programmes MOLAB et FIXLAB), les archives allaient ainsi être considérées comme un outil de recherche à part entière, pour la première fois dans un projet européen porté par un consortium de laboratoires.
Among the transnational accesses offered, the CHARISMA project included a new program, ARCHLAB, involving the archives of six laboratories. Managed by the Archives and Documentation Department of the Centre de Recherche et de Restauration des Musées de France (C2RMF, research and conservation center of the French museums), this program subsidized access to documentation and archives of cultural heritage laboratories located in five European countries: the British Museum and the National Gallery (London), the C2RMF (Paris), the Prado museum (Madrid), the Rijksdienst voor het Cultureel Erfgoed (RCE, cultural heritage agency of the Netherlands, Amsterdam) and the Opificio delle Pietre Dure (Florence). These institutions do have exceptional documentary holdings, established since their inception, for some, as early as the $1930 \mathrm{~s}^{2}$. Just as scientific instruments and facilities (MOLAB and FIXLAB programs ${ }^{3}$ ), the archives would thus be regarded as full research facilities for the first time in a European project led by a consortium of laboratories. 


\section{Le programme ARCHLAB}

Le fonctionnement d'ARCHLAB reposait sur les principes antérieurement définis pour les autres programmes de l'accès transnational. À l'issue d'une procédure de sélection des projets, des chercheurs européens ${ }^{3}$ pouvaient ainsi bénéficier d'un séjour d'une semaine dans un ou plusieurs des laboratoires d'accueil, qui s'engageaient à mettre à leur disposition la documentation scientifique en rapport avec leur sujet de recherche. Ce matériel documentaire comprenait non seulement les rapports d'étude, mais aussi les bases de données, l'imagerie scientifique et les prélèvements effectués dans le cadre d'analyses, que les chercheurs pouvaient également examiner. Dans un contexte économique particulièrement difficile, l'intérêt d'ARCHLAB pour les chercheurs ne se limitait pas à un soutien financier. En effet, ils allaient bénéficier non seulement de l'assistance de documentalistes tout au long de leur séjour, mais aussi de l'expertise de chercheurs de l'institution d'accueil, spécialistes de leur domaine d'étude.

La gestion du programme et la coordination de ses activités étaient assurées par un bureau d'accueil (Welcome Desk) composé de représentants de chaque laboratoire, pour la plupart ingénieurs de recherche ${ }^{4}$ (fig. 1). Chaque semestre, à l'issue d'un appel à projets ${ }^{5}$, les dossiers déposés par les candidats étaient examinés et sélectionnés par un comité (Peer review panel) composé d'experts extérieurs ${ }^{6}$ au consortium CHARISMA et du coordonnateur d'ARCHLAB. Cet organe jouait un rôle crucial dans la réussite du programme, en évaluant la pertinence scientifique des projets de recherche soumis, une fois leur faisabilité vérifiée par le bureau d'accueil. Ce dernier pouvait ainsi émettre un avis défavorable si les sources s'avéraient insuffisantes, ou si la recherche portait sur des dossiers en cours de publication.

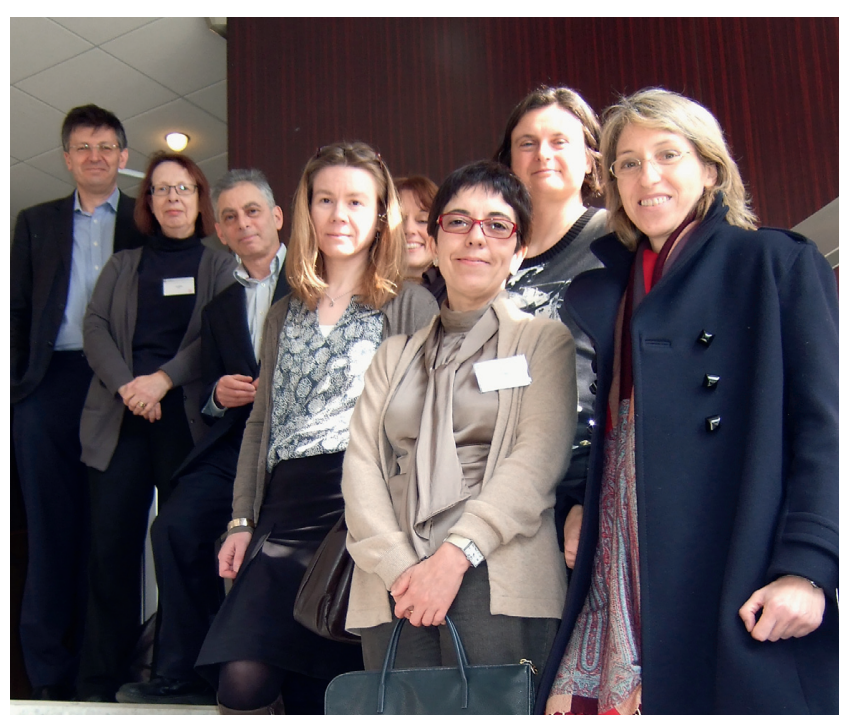

Fig. 1. Le Welcome Desk d'ARCHLAB au KIK-IRPA en 2012 : David Saunders, Ashok Roy, Marika Spring, Monica Galeotti (au second plan), Maria Dolores Gayo-Garcia, Ineke Joosten, Clémence Raynaud (au premier plan). @ Joëlle Crétin.

\section{The ARCHLAB program}

The ARCHLAB operation was based on principles previously defined for other transnational access programs. Following the proposal selection procedure, European researchers ${ }^{4}$ could be granted a one-week stay in one or more host laboratories, which undertook to make available scientific documentation related to their research topic. This documentary material included not only study reports, but also databases, scientific imaging and samples taken for analysis purpose that the researchers could also examine. In a particularly difficult economic context, the advantage of ARCHLAB for researchers was not limited to financial support. Indeed, they would benefit not only from the assistance of librarians throughout their stay, but also from the expertise of researchers from the host institution, specialists in their field of study.

Program management and coordination of its activities were carried out by a Welcome Desk made up of representatives from each laboratory, mostly research engineers ${ }^{5}$. Each semester, following a call for proposals ${ }^{6}$, the applications sent by the candidates were examined and selected by a Peer Review Panel composed of experts ${ }^{7}$ external to the CHARISMA consortium and to the ARCHLAB coordinator. This committee played a crucial role in the success of the program, assessing the scientific relevance of the submitted research proposals, once their feasibility was checked by the Welcome Desk. The latter could express an unfavorable opinion if archival sources proved insufficient, or if the research was on files currently being published.

\section{The scientific assessment}

If the results of the very first calls for proposals were relatively disappointing in quantitative terms, the communication efforts carried out by the whole consortium were soon very successful. Thus, at the end of the CHARISMA project, in March 2014, the objectives were fully achieved, with a total of ninety-seven research proposals selected out of one hundred and fifty-seven received and reviewed proposals. The proposals' origin, from twenty-one European Union countries (fig. 1), shows that the program was able to reach a very broad community of researchers. In four years, the number of subsidized access days adds up to five hundreds and seventeen, for a total of one hundred and twenty-five researchers received in the six laboratories.

From a strictly scientific standpoint, the program's impact can be objectively assessed against publications (seventeen), oral presentations (seventeen) and posters identified as resulting from ARCHLAB subsidized accesses. The analysis of the beneficiaries' scientific profiles shows a strong majority of researchers in sciences applied to cultural heritage. If the very small minority of art historians and archaeologists may be the expression of the current limits of the interdisciplinary of this field of study, however, a remarkable number of conservators were able to take advantage of this program as part 


\section{Le bilan scientifique}

Si les résultats des tout premiers appels à projets se sont avérés relativement décevants en termes quantitatifs, les efforts de communication portés par l'ensemble du consortium ont rapidement été très fructueux. Ainsi, à l'issue du projet CHARISMA en mars 2014, les objectifs fixés étaient pleinement atteints, avec un total de quatre-vingt-dix-sept projets de recherche (proposals) sélectionnés sur cent cinquante-sept projets reçus et examinés. La provenance des projets, issus de vingt et un pays de l'Union européenne (fig. 2), montre que le programme a réussi à toucher une très large communauté de chercheurs. En quatre années, le nombre de jours d'accès subventionnés s'élève à cinq cent dix-sept pour un nombre total de cent vingt-cinq chercheurs reçus dans les six laboratoires.

Sur un plan strictement scientifique, les retombées du programme peuvent objectivement être évaluées à l'aune des publications (dix-sept), communications orales (dix-sept) et posters recensés à la suite des accès subventionnés par ARCHLAB. L'analyse des profils scientifiques des bénéficiaires révèle une forte majorité de chercheurs en sciences appliquées au patrimoine. Si le nombre très minoritaire d'historiens de l'art et d'archéologues traduit peut-être les limites actuelles de l'interdisciplinarité dans ce champ d'étude, on note en revanche qu'un nombre remarquable de restaurateurs ont pu profiter de ce programme dans le cadre de projets de restauration. Certains séjours de recherche ont même concerné des chantiers majeurs conduits simultanément sur des chefsd'œuvre du patrimoine européen. Ainsi la restauratrice Muriel Vervat a-t-elle pu examiner la documentation constituée au C2RMF et à la National Gallery de Londres sur les panneaux of conservation projects. Some research stays were even related to major conservation projects simultaneously carried out on masterpieces of European heritage. Thus, the conservator Muriel Vervat was able to examine the documentation gathered at the C2RMF and at the National Gallery in London on the Battle of San Romano panels by Paolo Uccello kept in the Louvre museum and the National Gallery, prior to the conservation of the Uffizi Gallery panel in Florence (see, in this volume, article by Muriel Vervat). ARCHLAB also enabled two members ${ }^{8}$ of the team responsible for the conservation of the Ghent Altarpiece (also called the Adoration of the Mystic Lamb, Saint Bavo cathedral, Ghent) to consult the documentation at the C2RMF, the National Gallery in London and the Prado museum on the works and painting techniques of the Van Eyck brothers.

To some extent, the results provide a unique snapshot of European research in the field of sciences applied to cultural heritage. They reveal the significant imbalances between different areas. Among the selected projects, a clear majority relates to easel paintings. If archaeology then appears as one of the most dynamic sectors, book and paper, photography, technical and industrial heritage, sculpture or art objects (textiles, furniture, silversmith's and goldsmith's works) are particularly in a minority, when they are not simply absent. Wishing to encourage research in all heritage areas, the ARCHLAB program nonetheless subsidized a substantial number of projects conducted on original subjects. This is the case, for example, of research on musical instruments varnishes done by Jean-Philippe Echard ${ }^{9}$ (musée de la Musique, Paris), or of work carried out by French and Italian teams ${ }^{10}$ on the development of scientific research on cultural heritage in the 1930 s in Europe.
Fig. 2. Provenance des candidatures (en \%). Nationalities of applicants.

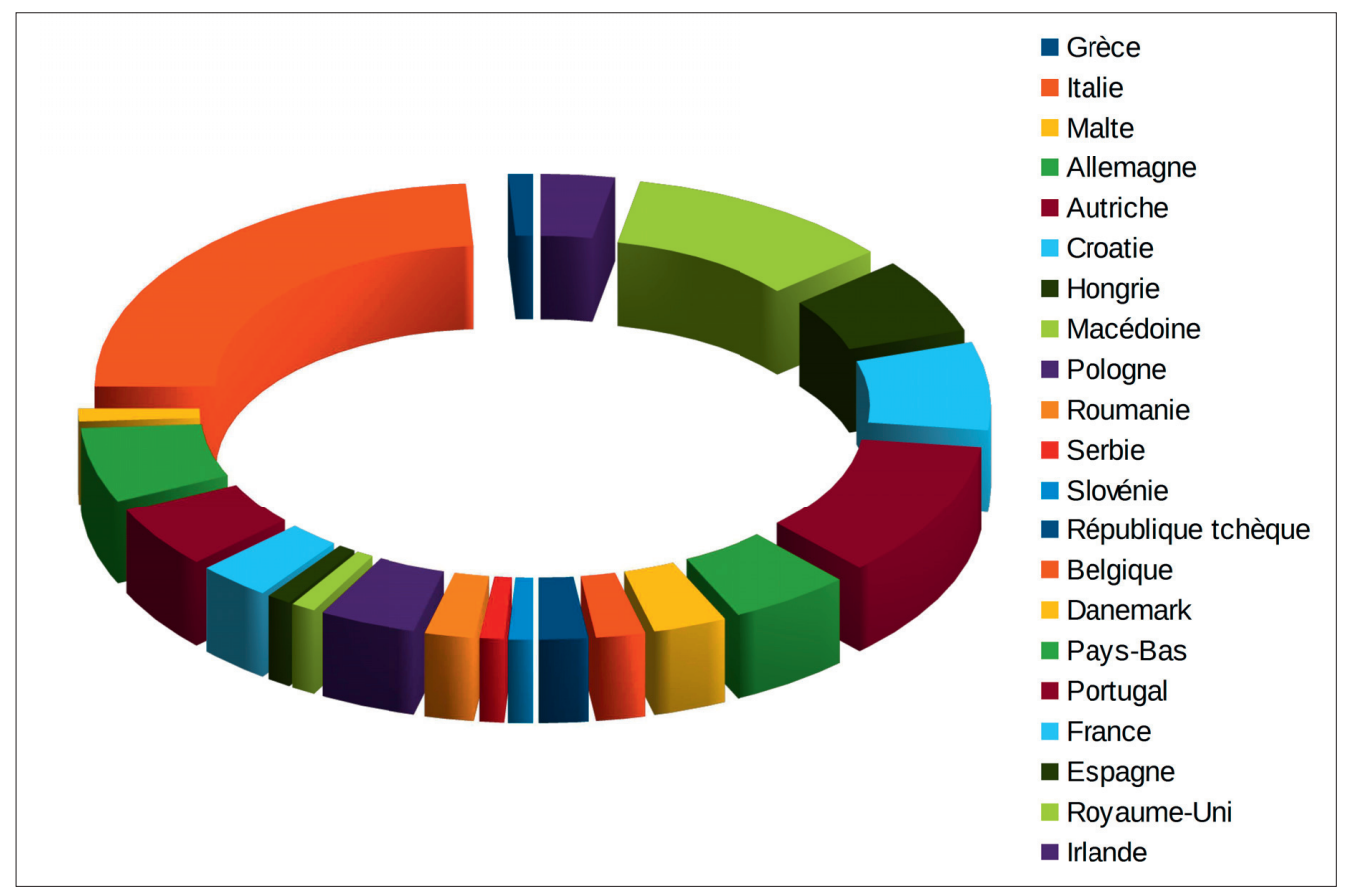


de la Bataille de San Romano de Paolo Uccello, conservés au musée du Louvre et à la National Gallery, préalablement à la restauration du panneau des Offices à Florence (voir dans ce volume l'article de Muriel Vervat). ARCHLAB aura également permis à deux membres ${ }^{7}$ de l'équipe chargée de la restauration du Polyptyque de l'Agneau mystique (cathédrale Saint-Bavon, Gand) de consulter la documentation établie au C2RMF, à la National Gallery de Londres et au musée du Prado sur les œuvres et la technique picturale des frères Van Eyck.

Dans une certaine mesure, les résultats fournissent une photographie inédite de la recherche européenne dans le champ des sciences appliquées au patrimoine. Ils en révèlent les importants déséquilibres entre les différents domaines. Parmi les projets sélectionnés, on relève ainsi une nette majorité de sujets portant sur la peinture de chevalet. Si l'archéologie apparaît ensuite comme l'un des secteurs les plus dynamiques, les arts graphiques, la photographie, le patrimoine technique et industriel, la sculpture ou encore les objets d'art (textile, mobilier, orfèvrerie) sont particulièrement minoritaires, quand ils ne sont pas simplement absents. Souhaitant encourager la recherche dans tous les domaines patrimoniaux, le programme ARCHLAB a néanmoins subventionné un nombre substantiel de projets conduits sur des sujets originaux. C'est le cas, par exemple, des recherches menées sur les vernis des instruments de musique par JeanPhilippe Echard ${ }^{8}$ (musée de la Musique, Paris), ou des travaux réalisés par des équipes française et italienne ${ }^{9}$ sur l'essor de la recherche scientifique sur le patrimoine en Europe dans les années 1930.

\section{Contribuer au développement des échanges et de la collaboration scientifique}

L'intérêt d'ARCHLAB aurait été limité si le programme n'avait pas eu aussi pour enjeu, au-delà des objectifs strictement contractuels, de favoriser les échanges entre les chercheurs et les institutions des pays membres de l'Union européenne. De ce point de vue, les rencontres organisées par le bureau d'accueil entre les bénéficiaires d'ARCHLAB et les spécialistes des laboratoires d'accueil, auxquels se sont joints parfois des conservateurs de musée, ont sans doute constitué l'un des apports les plus intéressants du dispositif. Ainsi, dans un certain nombre de cas, les accès ont été déterminants pour la réalisation de projets collectifs impliquant ces laboratoires d'une part et, d'autre part, les institutions des chercheurs bénéficiaires. C'est le cas, notamment, de l'accès dont ont bénéficié Marc Étienne (musée du Louvre, département des Antiquités égyptiennes) et Benoit Mille (CNRS) au Scientific Department du British Museum pour des recherches consacrées aux techniques de fabrication des bronzes égyptiens antiques, associant le C2RMF, le musée du Louvre et le British Museum. A contrario, certains projets se sont avérés décevants faute de véritables échanges avec les chercheurs invités, aucun retour scientifique n'ayant été reçu en dépit de l'investissement fourni par les institutions d'accueil.

\section{Contribution to development of scientific exchange and collaboration}

The interest of ARCHLAB would have been limited if the project had not also at stake, beyond the strictly contractual objectives, to promote exchange between researchers and institutions of European Union member countries. From this point of view, the meetings organized by the Welcome Desk between ARCHLAB beneficiaries and specialists in host laboratories, sometimes together with museum curators, may have been one of the most interesting contributions of the scheme. Thus, in a number of cases, providing access has been crucial for the realization of collective projects involving on the one hand, these laboratories, and on the other hand, the institutions of the beneficiary researchers. This is the case, among others, of the access granted to Marc Étienne (the Louvre museum, Egyptian Antiquities Department) and Benoit Mille (CNRS) to the Scientific Research Department of the British Museum to carry out research on Egyptian bronzes manufacturing techniques, a joint project of the C2RMF, the Louvre Museum and the British Museum. Conversely, some projects have been disappointing due to the lack of real exchanges with visiting researchers, no scientific return having been received despite the investment provided by the host institutions.

Thanks to the semi-annual meetings and the ongoing exchange between the members of the Welcome Desk, ARCHLAB has finally enabled the emergence of a European network of archives of the significant laboratories dedicated to cultural heritage, which scientific benefits should be lasting. Indeed, renewed under the IPERION CH project (2015-2019), ARCHLAB should not only consolidate the links established by CHARISMA, but also develop them through the expansion of the network, reinforced by four new laboratories in Germany, Belgium, Denmark and Spain ${ }^{11}$. The program leadership, provided by the C2RMF for four years, now falls to KIK-IRPA, another European pioneer in the field of documentation applied to the study and conservation of cultural heritage.

Beyond the results for which it was committed to the European Commission, which fully confirm the interest of such a program for researchers, CHARISMA has contributed significantly to the establishment of the ARCHLAB platform, to the promotion of laboratories archives and to the collaboration between institutions ${ }^{12}$. Fostering their international influence, it has also helped in the conservation of these unique archival holdings, which traditionally have been granted much smaller funds to those attributed to scientific facilities. Indeed, the laboratories participation in ARCHLAB was accompanied by compensation that allowed departments responsible for these archives to speed up their dematerialization (digitization, indexing) and to renew their equipment (reconditioning material, storage cabinets, etc.). Lastly, the ARCHLAB results confirm the potential of archives considered as scientific exchange platforms. By encouraging access to and exploitation of these archives built up for decades, this program has undoubtedly given them a new role in the development of research applied to cultural heritage. 
Grâce aux réunions semestrielles et aux échanges permanents entre les membres du bureau d'accueil, ARCHLAB a enfin permis l'émergence d'un réseau européen des archives de grands laboratoires voués au patrimoine, dont les retombées scientifiques devraient être durables. En effet, renouvelé dans le cadre du projet IPERION CH (2015-2019), ARCHLAB devrait non seulement consolider les liens établis par CHARISMA, mais aussi les développer grâce à l'élargissement du réseau, renforcé par quatre nouveaux laboratoires situés en Allemagne, en Belgique, au Danemark et en Espagne ${ }^{10}$. Le leadership du programme, assuré par le C2RMF pendant quatre années, échoit à présent au KIK-IRPA, autre pionnier européen dans le domaine de la documentation appliquée à l'étude et à la conservation du patrimoine.

Au-delà des résultats pour lesquels il s'était engagé auprès de la Commission européenne, qui confirment pleinement l'intérêt d'un tel programme pour les chercheurs, CHARISMA a donc fortement contribué, en mettant en place la plateforme ARCHLAB, à la promotion des archives de laboratoires et au travail collaboratif entre les institutions ${ }^{11}$. Favorisant leur rayonnement international, il a également aidé à la conservation de ces fonds uniques, qui bénéficient traditionnellement de dotations très inférieures à celles attribuées aux installations scientifiques. En effet, la participation des laboratoires à ARCHLAB s'est accompagnée de contreparties qui ont permis aux services chargés de ces archives d'accélérer leur dématérialisation (numérisation, indexation) et de renouveler leurs équipements (matériel de reconditionnement, meubles de stockage, etc.). Les résultats d'ARCHLAB confirment, enfin, le potentiel des archives considérées comme plateformes d'échanges scientifiques. En incitant à l'accès et à l'exploitation de ces fonds constitués depuis des décennies, ce programme leur a incontestablement conféré un rôle nouveau dans le développement de la recherche appliquée au patrimoine.

\section{Remerciements}

Les auteurs tiennent à exprimer leur reconnaissance au coordonnateur général du projet CHARISMA, Bruno Brunetti, dont le soutien infaillible a été déterminant tout au long du programme, ainsi qu'à Christiane Naffah, directrice du C2RMF de 2005 à 2010, dont l'appui fut décisif dans sa mise en place. La réussite d'Archlab doit également beaucoup à l'efficacité et au dévouement des membres et collaborateurs du Welcome Desk (Monica Galeotti, Maria-Dolores Gayo-Garcia, Catherine Higgitt, Ineke Joosten, Maïte Jover, Ashok Roy, David Saunders, Marika Spring et Maarten Van Bommel), dont nous saluons ici l'esprit d'ouverture et de solidarité. Enfin, le considérable travail de sélection réalisé par Vincent Serneels, Michael Tite et Jørgen Wadum au sein du Peer Review Panel fut crucial pour la réussite scientifique du programme. Que tous trouvent ici l'expression de nos plus vifs remerciements.

\section{Acknowledgements}

The authors wish to express their gratitude to the overall CHARISMA project coordinator, Bruno Brunetti, whose unfailing support has been crucial throughout the program, as well as to Christiane Naffah, C2RMF director from 2005 to 2010, whose support was decisive in its implementation. The success of Archlab also owes much to the efficiency and dedication of the members and contributors of the Welcome Desk (Monica Galeotti, Maria Dolores Garcia-Gayo, Catherine Higgitt, Ineke Joosten, Mä̈te Jover, Ashok Roy, David Saunders, Marika Spring and Maarten Van Bommel), we here salute their spirit of openness and solidarity. Finally, the significant selection work carried out by Vincent Serneels, Michael Tite and Jørgen Wadum within the Peer Review Panel was crucial for the scientific success of the program. Our most sincere thanks go to all.

(Traduction en anglais : Elsa Bourguignon.)
Notes

1. Coordonnateurs du programme ARCHLAB : Clémence Raynaud (2009 2012), puis Joëlle Crétin (2013-2014).

2. C'est le cas, notamment, du British Museum et du C2RMF (sur les fonds anciens du C2RMF, voir Raynaud, 2014).

3. Seuls les ressortissants d'un pays membre de l'Union européenne sont éligibles.

4. ARCHLAB Welcome desk: Monica Galeotti (Opificio delle Pietre Dure), MariaDolores Gayo-Garcia (Prado), David Saunders (British Museum), Marika Spring (National Gallery of London), Clémence Raynaud et Joëlle Crétin (C2RMF), Maarten Van Bommel et Ineke Joosten (OCW-RCE).

5. Au total, neuf appels à projets ont été organisés.

6. Vincent Serneels (université de Fribourg, Suisse), Michael Tite (université
d'Oxford, Royaume-Uni) et Jørgen Wadum (National Gallery of Denmark, Danemark). 7. Hélène Dubois (Institut royal du patrimoine artistique, Bruxelles) et Marie Postec (école La Cambre, Bruxelles), restauratrices de peintures.

8. Jean-Philippe Echard, Studies of series of lake-containing model paint sample, recherches réalisées à la National Gallery de Londres en 2011.

9. Projets portés par Camille Bourdiel, Francesca Nucera, Maria Ida Catalano, Gabriella Prisco et Angela Cerasuolo. 10. Stiftung Preussischer Kulturbesitz Staatliche Museen zu Berlin, Institut royal du patrimoine artistique (Bruxelles), Centre for Art Technological Studies and Conservation (Copenhague), Instituto del Patrimonio Cultural de España (Madrid). 11. Voir Raynaud, 2013-2014.
Bibliographie

Galeotti M., 2012, «L'Europa incontra l'Opificio con ARCHLAB », OPD Restauro, $\mathrm{n}^{\circ} 24$, p. 302-303.

Raynaud C., 2014, «Les dossiers de restauration du Centre de recherche et de restauration des musées de France (C2RMF) : vers une reconnaissance patrimoniale ", in Documenter les collections des musées. Investigation, inventaire, numérisation et diffusion, dir. Claire Merleau-Ponty, La Documentation française, Paris, p. 173-187.

Raynaud C., 2013-2014, " Archlab : les archives au cœur de la recherche scientifique sur le patrimoine ", Culture et recherche, $\mathrm{n}^{\circ} 129$, p. 23. 